\title{
An inquisitive enquiry of work-life balance of employees: Evidences from Kingdom of Saudi Arabia
}

\author{
Zafrul Allama*
}

${ }^{a}$ Assistant Professor, Department of Human Resource Management, Prince Sattam bin Abdulaziz University, Post box: 165, Al-Kharj11942, Kingdom of Saudi Arabia

C H R O N I C L E

Article history:

Received: October 2, 2018

Received in revised format: November 15, 2018

Accepted: November 18, 2018

Available online:

November 18, 2018

Keywords:

Saudi Arabia

$W L B$

Performance

Personal life

\begin{abstract}
A B S T R A C T
This paper attempts to find out various facets of work-life balance (WLB) contribution and relationships with the employees' working in dairy company in the Kingdom of Saudi Arabia. The study considers 131 employees selected randomly from the Nadec dairy company. Work-life balance Scale developed and standardized by Pareek et al. (2011) [Pareek, U., Purohit, S., \& Joshi, A. (2011). Training instruments in HRD and OD. New Del-hi: Tata McGraw- Hills Publishing Company Limited. 287-289.] was used to gather the information from the respondents. Both descriptive and inferential statistics are been used to analyze the data. The most prominent findings of the result are: (i) all the facets of work-life balance have positive relationships with each other except teamwork; (ii) married are scored high in terms of mean on time management and teamwork which statistically indicates an existence of significant difference in contrast to their counterparts and (iii) social needs a component of work-life balance appears as one of the most powerful predictors of personal needs within the employees' working in the dairy company. The current investigation is an eye-opener for HR professional in the Kingdom to design and implement the certain mechanism to improve the work-life balance of the employees to achieve the Saudi Vision 2030 .
\end{abstract}

\section{Introduction}

During the last three decades, many researchers, academicians and human resources (HR) professionals have talked about the employees work-life balance (WLB) because imbalance work life may create some problems for organizations, employees and families and finally this can reduce the performance of the organizations. Therefore, researchers still are interested in learning more about the outcome and the effects of WLB and strategies to minimize the imbalance and provide certain mechanism to balance the employees' professional lives in an effective way to enhance the productivity of the organization and make them happy. In a simple sentence WLB is a comfortable equilibrium division of one's duration between personal and professional life. Kofodimos (1993) was the first who defined WLB "as satisfaction and a sense of harmony between different aspects of life like work, play and love" but the term came into existence in 1986 although WLB programs were seen in 1930. According to Greenhaus

* Corresponding author.

E-mail address: z.allam@psau.edu.sa (Z. Allam) 
and Powell (2003), "WLB as the degree to which a person is involved in his or her work and non-work activities and described three types of balance: time balance (same time between job and personal life), involvement balance (same psychological participation in job and life) and satisfaction balance (equal satisfaction between job and personal life)". Deery (2008) conceptualized WLB as "of a complex task as it can be viewed from each the meaning of work, life and balance itself". However, Clark (2000) pointed out that "a state that occurs when there is a sense of satisfaction with work and family roles". These definitions provide that personal and professional lives are very important and meaningful otherwise, this will lead to develop negative attitude among the individuals. According to Mathew and Panchanatham (2011), dependent care issues, problems in time management, role overload, quality of health, and lack of proper social support are the prominent issues, which influence the WLB. Thus, WLB is an amazing and valuable concept in the business scenario as it inspires the workers and enhances their trustworthiness towards the works to make the company more profitable.

\section{Review of Literature}

Based on the earlier researches and findings, there seems to be a relationship between work-life balance and different variables. The scholars on the globe carried out the researches on job satisfaction, burnout, commitment, involvement, role conflict, stress, workload, absenteeism, motivation, turnover, intention to leave, etc. (Omar, et al., 2015; Azeem \& Akhtar, 2014; Allam, 2017; Tavassoli \& Sune, 2018; Allam \& Habtemariam, 2009; Al Kahtani \& Allam, 2013; Allam, 2007) and directly or indirectly linked with personal and professional life balance. They believed that work-life balance can be enhanced by the management of these variables to make them more effective at their workplace. Work-life balance is very much responsible in shaping the attitude of the employees and their personal lives. Out of various factors which affect the efficiency of the workers at workplace, work-life balance is one of them. Those having balanced life and career most probably seem to be more effective in the work and vice versa. One of the challenges is to balance between personal and family life because it has greater influence on employees' life and work (Scholarios \& Marks, 2004; Broers, 2005). Omar et al. (2015) conducted a study among employees working in the Malaysian government reinforcement agency. They analyzed the data by using both inferential as well as descriptive statistics to get the results to achieve the formulated objectives. Their intention was to explore the influence of role conflict and workload on worklife balance. They found that workload was the foremost factor affecting the work-life balance and followed by role conflict. Further, they pointed out that both factors were significantly associated with work-life balance in the form of negativism. It indicates that greater degree of role conflict and workload experienced by the workers might lead to lessen work-life balance among the employees. Padmasiri and Mahalekamge (2016) initiated a study among academic staff working at the university of Sri Lanka to probe the impact of demographical variables on work-life balance. They revealed that significant association exists among, marital status, gender and work-life balance. Further, they reported that married people were having lesser degree of work-life balance compared with their counterparts. Wong et al. (2017) studied on service sectors employees to explore the association between work-life balance and workplace factors. They analyzed the data with the help of rho techniques to get the relationships among the variables taken into study. They observed positive relationship between work-life balance with co-worker \& supervisor support and flexible working arrangement among Malaysian service sectors employees. However, they provided some insight to the management to establish some processes to make the work-life balance more appropriate at workplace to enhance the efficiency of the employees.

\section{The aims of the investigation}

Based on the literature available, it is observed that many studies were conducted on several issues of organizational development and behaviour such as job attitude, HRM practices, HR innovations, quality of work life, management of stress etc., to improve the productivity of the organizations. But the researcher felt that very limited studies are available on "work-life balance" in the context of Saudi 
Arabia. Henceforth, the investigator planned to have a study on "work-life balance" among employees working in dairy company and formulated the following objectives,

- To identify the contribution and relationship of personal needs with other domains of work-life balance among dairy company employees,

- To determine the predictor of personal needs on the aspects of WLB among employees,

- To find out the effect of social status on different aspects of WLB among dairy company employees.

\section{Hypotheses}

The researcher formulated few objectives and reviewed the various published articles; henceforth based on these, the following null hypotheses were prepared to verify the results.

$\mathrm{H}_{01}$ : There is a difference between unmarried and married employees on the various aspects of worklife balance.

$\mathrm{H}_{02}$ : There is a significant relationship between the various aspects of work-life balance.

$\mathrm{H}_{03}$ : There is not any predictors of social statuses within the aspects of work-life balance.

\section{Research Methodology}

\subsection{Sample}

There were 131 employees included in the study and they were selected randomly from the Nadec dairy company located at Kingdom of Saudi Arabia. The respondents' age, experiences etc. were varied.

Measures and Tools: The following measures and tools were taken into consideration to collect the information from the employees for the motif of the study.

Work-life balance Scale: This was used to gather the information from the respondents developed, conceptualized and standardized by Pareek et al. (2011). There were thirty six items in the questionnaire and each item required to rate on the continuum of five point rating scale with a response indicator of "if it is not true to if it is definitely true" with the weighted score of 0-4. This particular scale consists of six dimensions namely "social needs, personal needs, time management, team work, compensation $\&$ benefits and work" and each dimension is having six items in every dimension. The reliability and validity of the scale were established.

Demographical Information Sheet: Separate sheet was used to get the information of personal characteristics of the respondents such as nationality, age, social status, gender etc.

Statistics: Both descriptive and inferential statistics have been used to analyze the data to get meaningful results as per the design of the study.

Procedure and Ethics: The questionnaire was in English and it was translated into Arabic version so that the respondents could understand what the researcher intended to say. Further, translation was performed by some experts to maintain the lucrative of the questions. The questionnaire was distributed among employees working in different units of Nadec dairy company, and were given ample time to fill in the questionnaires. Instruction was clearly given to the respondents and informed them in advance that this study was for academic purpose and would never disclose to anyone under any circumstances. The collected data was tabulated and analysed with the support of excel sheet as well as SPSS. 


\section{Result and discussions}

Fig. (1.a) represents the social status of the respondents working in the Nadec Company in Kingdom of Saudi Arabia. Out of 131, 63.4 percent were married and 36. 6 percent were single. The figure reflects that the majority of the employees in the organization were married in terms of their social status. Fig. (1.b) depicts the gender of the total number of $131 \mathrm{employees}$ in the investigation. It is evident from the Fig. (1.b) that male was 64.1 percent and female was 35.9 percent, respectively, out of 131 employees.

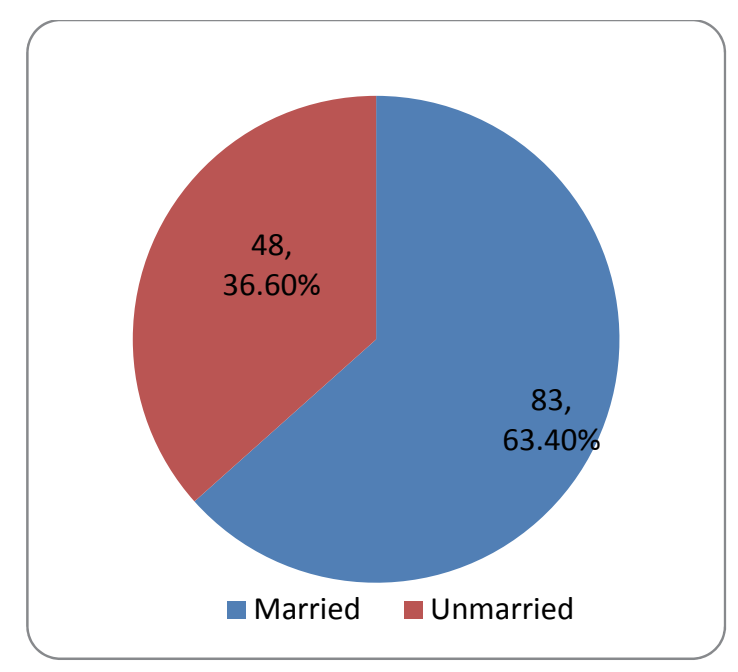

(a) Social Status

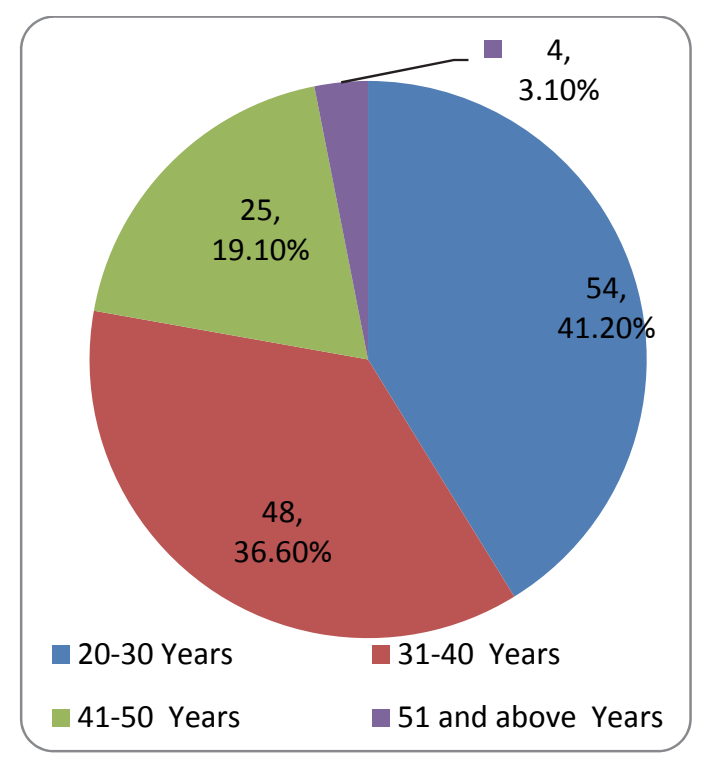

(c) Age

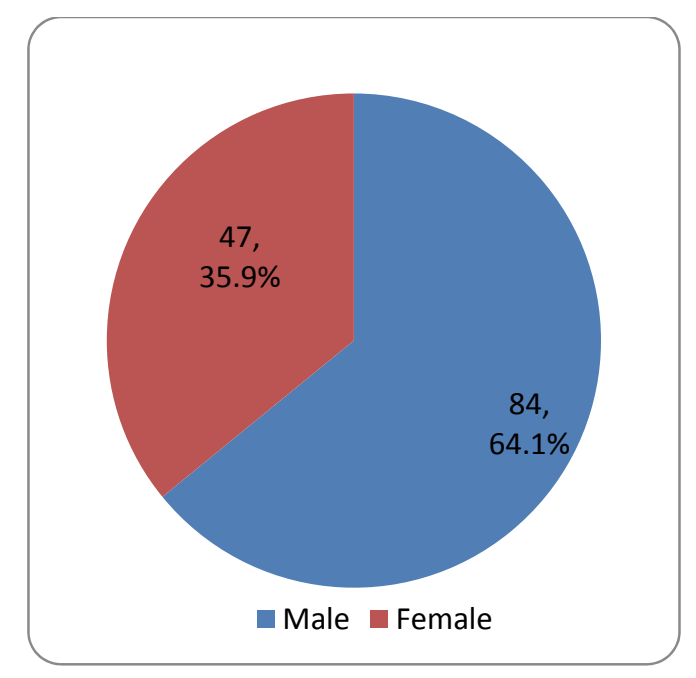

(b) Gender

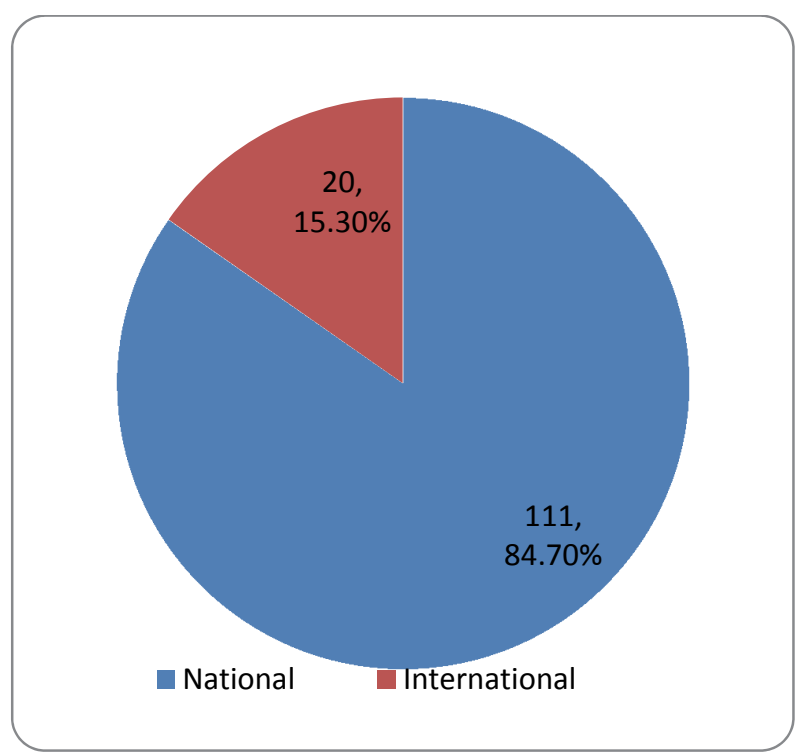

(d) Nationality

Fig. 1. Personal characteristics of the respondents

The result indicates that majority of the employees working in the company were male in contrast to female counterpart. Fig. (1.c) demonstrates the age of 131 employees under the current investigation. It can be seen from the figure that out of 131 respondents, 41.2 percent were in the age group between 20-30 years, 36.6 per cent between 31-40 years, 19.1 percent are fall in the categories of 41-50 years of age and 3.1 per cent are 51 and above years of categories respectively. The finding reflects that most of the incumbents were younger in age group in diary Company. This particular Fig. (1.d) explained 
the nationality of the employees. However, national employees refer to Saudi and international indicates about the expatriates working in the company. It is observed that out of $131,84.7$ per cent employees employed in the organization were citizen of Saudi and 15.3 percent belonged to other countries. Results have found that company was striving hard to make the organization towards the Saudization and given due weight age to the local people to work in the organization and accelerate the development initiated by the government.

\section{Table 1}

Mean, SD and t-value of social status of employees on various aspects of work-life balance

\begin{tabular}{|c|c|c|c|c|c|}
\hline Domains of Work-life balance & Social Status & $\mathrm{N}$ & Mean & Std. Deviation & t-value \\
\hline \multirow[t]{2}{*}{ Social Needs } & Married & 83 & 13.64 & 4.119 & \multirow{2}{*}{.713} \\
\hline & Unmarried & 48 & 14.17 & 4.018 & \\
\hline \multirow[t]{2}{*}{ Personal Needs } & Married & 83 & 14.30 & 4.552 & \multirow{2}{*}{.589} \\
\hline & Unmarried & 48 & 13.83 & 4.055 & \\
\hline \multirow[t]{2}{*}{ Time Management } & Married & 83 & 13.45 & 3.387 & \multirow{2}{*}{$2.419 * *$} \\
\hline & Unmarried & 48 & 12.02 & 2.993 & \\
\hline \multirow[t]{2}{*}{ Team Work } & Married & 83 & 15.30 & 3.399 & \multirow{2}{*}{$2.260 * *$} \\
\hline & Unmarried & 48 & 13.94 & 3.198 & \\
\hline \multirow[t]{2}{*}{ Compensation \& Benefits } & Married & 83 & 15.17 & 4.184 & \multirow{2}{*}{.974} \\
\hline & Unmarried & 48 & 14.46 & 3.724 & \\
\hline \multirow[t]{2}{*}{ Work } & Married & 83 & 14.18 & 3.041 & \multirow{2}{*}{.970} \\
\hline & Unmarried & 48 & 13.58 & 3.940 & \\
\hline
\end{tabular}

Significant at $* * \mathrm{P}>.01$

It is evident from Table 1 that mean scores of singles and married incumbents working in dairy company on different domains of work-life balance such as social needs (14.17 \& 13.64), personal needs (13.83 \& 14.30), time management (12.02 \& 13.45), team work (13.94 \& 15.30), compensation \& benefits $(14.46 \& 15.17)$ and work (13.58 \& 14.18) were observed having varied scores in SDs. The $\mathrm{t}$-value were observed for time management $(2.419, \mathrm{P}>.01)$ and team work $(2.260, \mathrm{P}>.01)$, it is essential to mention that the rest of the domain was not found statistically significant at any level and henceforth, the proposed null hypothesis $\left(\mathrm{H}_{01}\right)$ was partially accepted due to significant differences observed on only two aspects of work-life balance. It is observed that mean scores were higher among the married employees on time management as well as team work; which reflects that married employees prone to discharge the responsibilities as per the priority, sometimes extra hours work and easily mingles with the group to meet the requirements of colleagues and friends to act in a collaborative manner.

Table 2

Representing Mean, std. deviation and correlations matrix of work-life balance and their aspects

\begin{tabular}{|c|c|c|c|c|c|c|c|c|}
\hline Variables & Mean & S.D. & 1 & 2 & 3 & 4 & 5 & 6 \\
\hline 1. Social Needs & 13.83 & 4.075 & - & & & & & \\
\hline Personal Needs & 14.13 & 4.367 & $.624 * *$ & - & & & & \\
\hline 3. Time Management & 12.92 & 3.309 & $.319 * *$ & $.233 * *$ & - & & & \\
\hline 4. Team work & 14.80 & 3.380 & $.278 * *$ & $.424 * *$ & .166 & - & & \\
\hline 5. Compensation \& Benefits & 14.91 & 4.022 & $.576 * *$ & $.582 * *$ & $.299 * *$ & $.444^{* *}$ & - & \\
\hline 6. Work & 13.96 & 3.395 & $.431 * *$ & $.483 * *$ & $.269 * *$ & $263 * *$ & $.519 * *$ & - \\
\hline
\end{tabular}

Source: Data analyzed by using SPSS 16 Version

**. Correlation is significant at the 0.01 level (2-tailed).

Table 2 shows the descriptive statistics in the form of Mean, standard deviation (S.D.) and Pearson moment correlation between the domains of work-life balance of employees working in dairy company situated in the Kingdom. Further, it is found that out of six domains of work-life balance only one did not have any association but the rest of the domains were observed having significant relationships when the level of significance was one percent. Therefore the proposed hypothesis $\left(\mathrm{H}_{02}\right)$ was not statistically accepted. It means that employees were working in the team were not concerned about the 
time management and keeping away from the priority of work. However, other factors were intact with each other and maintained some relationships.

\section{Table 3}

Model summary stepwise multiple regression analysis for work-life balance aspects of social needs, time management, team work, compensation \& benefits and work with personal needs

\begin{tabular}{lccccc}
\hline Predictors & $\mathrm{R}$ & $\mathrm{R}^{2}$ & Adjust $\mathrm{R}^{2}$ & $\mathrm{R}^{2}$ Change & $\mathrm{F}$ Change \\
\hline a. Social Needs & .624 & .389 & .384 & .389 & $82.173^{* *}$ \\
b. Social Needs, Compensation \& Benefits & .681 & .463 & .455 & .074 & $17.731^{* *}$ \\
c. Social Needs, Compensation \& Benefits, Team Work & .703 & .494 & .482 & .030 & $7.653^{* *}$ \\
d. Social Needs, Compensation \& Benefits, Team Work, Work & .717 & .514 & .498 & .020 & $5.147^{*}$ \\
\hline
\end{tabular}

** Significant at .01 level * Significant at .05 level

a. Predictors: (Constant), Social Needs

b. Predictors: (Constant), Social Needs, Compensation \& Benefits c. Predictors: (Constant), Social Needs, Compensation \& Benefits, Team Work

d. Predictors: (Constant), Social Needs, Compensation \& Benefits, Team Work, Work e. Dependent variable: Personal Needs

\section{Table 4}

ANOVA of multiple regressions of various facets of work-life balance with personal needs among dairy employees

\begin{tabular}{|c|c|c|c|c|}
\hline Model & Sum of Squares & $\mathrm{df}$ & Mean Square & $\mathrm{F}$ \\
\hline \multirow[t]{3}{*}{ 1. Regression Residual } & 964.567 & 1 & 964.567 & $82.173 * *$ \\
\hline & 1514.227 & 129 & 11.738 & \\
\hline & 2478.794 & 130 & & \\
\hline \multirow[t]{3}{*}{ 2. Regression Residual } & 1148.802 & 2 & 574.401 & $55.281 * *$ \\
\hline & 1329.992 & 128 & 10.391 & \\
\hline & 2478.794 & 130 & & \\
\hline \multirow[t]{3}{*}{ 3. Regression Residual } & 1224.395 & 3 & 408.132 & $41.321 * *$ \\
\hline & 1254.399 & 127 & 9.877 & \\
\hline & 2478.794 & 130 & & \\
\hline \multirow[t]{3}{*}{ 4. Regression Residual } & 1273.628 & 4 & 318.407 & $33.289 * *$ \\
\hline & 1205.166 & 126 & 9.565 & \\
\hline & 2478.794 & 130 & & \\
\hline
\end{tabular}

It can be seen from Table 3 that in the initial step, social needs was emerged as one of powerful predictors of personal needs among the dairy employees working in the Kingdom. The correlation coefficient between social and personal needs $(\mathrm{R}=.624)$ portrayed that personal needs of the employees were inclined by this feature. The calculated value of $\mathrm{R}^{2}$ which indicate the quantity of variations in the personal needs was expressed by the regression model. It is observed for $62.4 \%$ variations, $(\mathrm{F}=82.173$, $\mathrm{P}>$.01) appeared on the dependent variable of the employees working in the diary firm. As far as the second step is concerned, compensation \& benefits found to be the most dominant predictor of personal needs among the employees working in the company. The correlation coefficients between predictor and personal needs (dependent variable) $(\mathrm{R}=.681)$ constitutes linear relationship. The coefficient of determination $\left(\mathrm{R}^{2}=.463\right)$ was accounted for $46.3 \%$ variation along with social need predictors, Fchange value is $(\mathrm{F}=17.731, \mathrm{p}>.01)$ for personal needs. The $\mathrm{R}$-square change (.074) was accounted for $7.4 \%$ variation of compensation $\&$ benefits along with social needs. The result showing in the third step that team work aspect of work-life balance was recognized as a dominant predictor with personal needs. The correlation coefficients between social needs and team work $(\mathrm{R}=.703)$ was statistically significant. The obtained value of $\mathrm{R}^{2}$ represents the magnitude of disparities in the dependent variable explored by the regression model. It is noticed for $49.4 \%$ of the variations, the value of $F$-change is $(\mathrm{F}=7.653, \mathrm{p}>$ $.01)$ in the social needs. Furthermore in the step four, work is an aspect of work-life balance emerged as one of the dominant factors for social needs among the employees. The R-Square value was found to be 0.514 or accounted for $51.4 \%$ variations which indicates the relationship existed between dependent variable and predictor, $\mathrm{F}$-change value is $(\mathrm{F}=5.147, \mathrm{p}>.05)$ for personal needs. It is observed from Table 4 that calculated F-ratio for social needs $(\mathrm{F}=82.173, \mathrm{p}>.01)$, compensation \& benefits $(\mathrm{F}=55.281$, 
$\mathrm{p}>.01)$, team work $(\mathrm{F}=41.321, \mathrm{p}>.01)$ and work $(\mathrm{F}=33.289, \mathrm{p}>.01)$ were significant and contributed to personal needs of the employees working in the diary company in Kingdom. Thereby, the proposed null hypothesis $\left(\mathrm{H}_{03}\right)$ was not partially rejected. Mas-Machuca et al. (2016), Wong et al. (2017) and Russo et al. (2015) supported the above findings and expressed that social support either by the coworkers or by the management play an important role for balancing the work and personal life. Indeed, if an employee is having either directly or indirectly role stress, job dissatisfaction, lack of involvement, imbalance emotions and unfair practices applied by the management, these issues may affect his/her work-life balance and downgrade the performance of the employees (Allam, 2007; Al Kahtani \& Allam, 2016; Allam, 2017; Allam, 2013; Allam \& Habtemariam, 2009; Al Kahtani \& Allam, 2013; Allam, 2011; Al Kahtani et al., 2016a,b).

\section{Conclusions}

The researcher has formulated the objectives and hypotheses have been accomplished and the following conclusions are listed on the basis of findings:

- It is observed that male, married, national, and younger in age group were dominating in the company.

- All the facets of work-life balance were found to have positive relationship with each other except team work.

- Married were scored higher in terms of mean on time management and team work which indicates significant difference in contrast to their counterparts.

- Social needs as a component of work-life balance appeared as one of the most powerful predictors of the personal needs within the employees working in the dairy company.

- Other variables of work-life balance such as compensation \& benefits, team work and work were also found to be the predictor of personal needs among employees working in the dairy company.

\section{Limitation and suggestions}

The researcher achieved the objectives through different findings but still there are some limitations which cannot be ignored. We try to present few limitations which need to be tackled by the future management scientists or researchers to maintain the realm of the scientific investigation to provide some insight to add value in their knowledge. The sample, questionnaires and statistical techniques were used in the present investigation with the alignment of the cognitive processes to verify some objectives in a dairy company located in the Kingdom of Saudi Arabia. Al Kahtani et al. (2016b) highlighted in his investigation in the context of Saudi Arabia that negative feelings towards the job pushed the individuals in a negative entropy to perform the task and finally make it difficult to balance the work life. Therefore, there is a need to suggest some mechanism to the management to adopt or initiate steps such as training, arrange some community activities, role clarity, arrange the holidays trip, management support etc., to eliminate the negative feelings of the employees towards their organization or job to have work-life balance for the enhancement of the efficiency of both; the employees and organization.

\section{Acknowledgement}

The author is very much grateful to Mr. Abdullah Saleh \& Mr. Abdulmajed Ali who selflessly helped us collect the necessary data.

\section{References}

Al Kahtani, N.S. \& Allam, Z. (2013). A comparative study of job burnout, job involvement, locus of control and job satisfaction among banking employees of Kingdom of Saudi Arabia. Life Science Journal, 10(4), 2135-2144. 
Al Kahtani, N.S. \& Allam, Z. (2016). A holistic approach to determine the relationships of sociobiographical variables with role ambiguity and role conflict. International Business Management, 10(15), 2795 280.

Al Kahtani, N.S., Nawab, A. K., \& Allam, Z. (2016a). Organizational role stress: An empirical perspective of university teachers of Kingdom of Saudi Arabia. International Journal of Applied Business and Economic Research, 14(9), 336-355.

Al Kahtani, N.S., Nawab, A. K., \& Allam, Z. (2016b). Unfair HRM practices in the telecom sector in Saudi Arabia. An empirical investigation of selected public and private sector companies. International Journal of Applied Business and Economic Research, 14(10), 6377-6396.

Allam, Z. (2007). A Study of Relationship of Job Anxiety and Job Burnout with Job Involvement among Bank Employees. Management and Labor Studies, 21(1), 30-38.

Allam, Z. (2011).Emotional Intelligence at Workplace: A Psychological Review. Global Management Review, $5(2), 71-80$.

Allam, Z. (2013). Job anxiety, organizational commitment and job satisfaction: An empirical assessment of supervisors in the state of Eritrea. International Journal of Development and Management Review, 8, 50-62.

Allam, Z. (2017). A scientific approach to understand role stress amongst business school teachers. Man in India, 97(10), 183-196.

Allam, Z., \& Habtemariam, R. (2009). Job involvement: A brief of literature. Management and Labor Studies, 34(3), 397-404.

Azeem, S.M., \& Akhtar, N. (2014). The influence of work-life balance and job satisfaction on organizational commitment of healthcare employees. International Journal of Human Resource Studies, 4(2), 18-24.

Broers, C. (2005). Career and Family: The role of Social Support.

Clark, S. C. (2000). Work/family border theory: A new theory of work/family balance. Human Relations, 53(6), $747-770$.

Deery, M. (2008). Talent management, work-life balance and retention strategies. International Journal of Contemporary Hospitality Management, 20(7), 792-806.

Greenhaus, J. H., \& Powell, G. N. (2003), When work and family collide: Deciding between competing role demands. Organizational Behaviour and Human Decision Processes, 90(2), 291-303.

Kofodimos, J. R. (1993). Balancing act. San Francisco: Jossey-Bass.

Mas-Machuca, M., Berbegal-Mirabent, J., \& Alegre, I. (2016). Work-life balance and its relationship with organizational pride and job satisfaction. Journal of Managerial Psychology, 31(2), 586-602.

Mathew, R.V., \& Panchanatham, N. (2011). An exploratory study on the work-life balance of women entrepreneurs in south India. Asian Academy of Management Journal, 16(2), 77-105.

Omar, M.K., Mohd, I.H., \& Ariffin, M.S. (2015). Workload, role conflict and work-life balance among employees of an enforcement agency in Malaysia. International Journal of Business, Economics and Law, 8(2), 5257.

Padmasiri, M.K.D., \& Mahalekamge, W.G.S. (2016). Impact of demographical factors on work-life balance among academic staff of university of Kelaniya, Sri Lanka. Journal of Education and Vocational Research, 7(1), 54-59.

Pareek, U., Purohit, S., \& Joshi, A. (2011). Training instruments in HRD and OD (3rd ed.) New Delhi: Tata McGraw- Hills Publishing Company Limited. 287-289.

Russo, M., Shteigman, A., \& Carmeli, A. (2015). Workplace and family support and work-life balance: Implications for individual psychological availability and energy at work. The Journal of Positive Psychology, 9760, 1-16.

Scholarios, D., \& Marks, A. (2004). Work-life balance and the software worker. Human Resource Management Journal, 14(2), 54-74.

Tavassoli, T., \& Sune, A. (2018). A national study on the antecedents and outcomes of work-life balance in Iran. PEOPLE: International Journal of Social Sciences, 3(3), 1616-1636.

Wong, P.Y., Bandar, N.F.A., \& Saili, J. (2017). Workplace factors and work-life balance among employees in selected services sector. International Journal of Business and Society, 18(S4), 677-684.

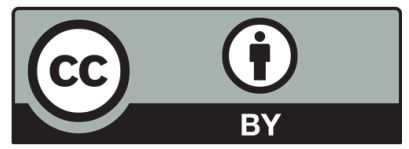

(C) 2019 by the authors; licensee Growing Science, Canada. This is an open access article distributed under the terms and conditions of the Creative Commons Attribution (CC-BY) license (http://creativecommons.org/licenses/by/4.0/). 